\title{
Gain-of-function p53 mutant with 21-bp deletion confers susceptibility to multidrug resistance in MCF-7 cells
}

\author{
SHANG-HSUN TSOU ${ }^{1}$, MING-HUNG HOU ${ }^{1}$, LIH-CHING HSU ${ }^{1}$, TZER-MING CHEN ${ }^{3}$ and YEN-HUI CHEN $^{1,2}$ \\ ${ }^{1}$ Graduate Institute of Pharmaceutical Sciences and ${ }^{2}$ Graduate Institute of Clinical Pharmacy, School of Pharmacy, \\ ${ }^{3}$ Department of Obstetrics and Gynecology, College of Medicine, National Taiwan University, Taipei 10050, Taiwan, R.O.C.
}

Received April 22, 2015; Accepted October 30, 2015

DOI: $10.3892 / \mathrm{ijmm} .2015 .2406$

\begin{abstract}
The majority of p53 mutations, which are responsible for gain of oncogenic function, are missense mutations in hotspot codons. However, in our previous study, we demonstrated that a deletion spanning codons 127-133 in the p53 gene (designated as del p53) was detected in doxorubicin-resistant MCF-7 cell lines following various induction processes. In the present study, we aimed to investigate the role of del p53 and its association with the proliferation, metastasis and drug resistance of MCF-7 cells. The MCF-7/del p53 cell line is a representative of the del p53 stably expressed clones which were constructed by transfection of the del p53-containing construct into MCF-7/wt cells. Markers of multidrug resistance (MDR), epithelial-mesenchymal transition (EMT) and stem cell-like properties were examined in the MCF-7/ del p53 cells. The results revealed that the MCF-7/del p53 cells expressed full-length p53 and del p53 mRNA and protein, as well as P-glycoprotein (P-gp). The MCF-7/del p53 cells acquired resistance to doxorubicin with increased P-gp efflux function. Using a transient expression assay, the MDR1 promoter was found to be significantly activated by external or integrated del p53 $(\mathrm{P}<0.001)$. The inhibition of nuclear factor (NF)- $\kappa \mathrm{B}$ by cyclosporine sensitized the MCF-7/del p53 cells to doxorubicin toxicity. In addition, the morphological characteristics of the MCF-7/del p53 and MCF-7/adr were similar. EMT was observed in the MCF-7/del p53 cells as demonstrated by the presence of the mesenchymal markers, Slug and vimentin, and the decrease in the epithelial marker, cadherin 1, type 1, E-cadherin (CDH1), as well as an enhanced
\end{abstract}

Correspondence to: Professor Yen-Hui Chen, Graduate Institute of Clinical Pharmacy, School of Pharmacy, College of Medicine, National Taiwan University, 33 Linsen South Road, Taipei 10050, Taiwan, R.O.C.

E-mail: tcyhchen@ntu.edu.tw

Abbreviations: ABC transporters, ATP binding cassette transporters; CSC, cancer stem cell; EMT, epithelial-mesenchymal transition; MDR, multidrug resistance; P-gp/ABCB1, P-glycoprotein

Key words: cancer stem cell-like cells, deleted p53, epithelialmesenchymal transition, multidrug resistance, nuclear factor- $\kappa \mathrm{B}$, P-glycoprotein migration ability $(\mathrm{P}<0.001)$. Furthermore, the number of cells expressing the cancer stem cell-like marker, CD44, increased, accompanied by mammosphere formation. Taken together, these findings indicate that the expression of del p53 in MCF-7/ del p53 cells enables the cells to partially acquire doxorubicin resistance characteristics of the MCF-7/adr cells. Thus, del p53 may be an important factor in non-invasive MCF-7 cells, activating $\mathrm{NF}-\kappa \mathrm{B}$ signaling and the MDR1 promoter and partially attributing to EMT; the cells thus acquire stem cell-like properties, which facilitates drug resistance. Therefore, the 21-bp deletion of p53 may prove to be a therapeutic strategy with which to prevent cancer cells from acquiring resistance to drugs.

\section{Introduction}

The p53 signaling pathway is activated in response to a variety of stress signals to facilitate the expression of genes mediating cell cycle arrest, DNA repair and apoptosis. Mutations in the p53 gene are the most common genetic abnormality found in human cancers (1) and may be regarded as a hallmark of cancer cells (2). However, mutant p53 proteins in cancer cells not only lose their tumor suppressor function, but often gain additional oncogenic functions that endow cells with growth and survival advantages, as well as metastastatic ability. Resistance to chemotherapy is also a phenotypic gain-of-function effect of p53 mutations. Mutant p53 proteins have been found in druginduced resistant cancer cell lines and in tumors following exposure to anticancer drugs (3). The p53 status has a significant impact on the resistance of cancer cells to chemotherapy. Thus, research has focused on identifying p53 mutations and their association with drug resistance (4).

Multidrug resistance (MDR) is the outcome of a series of mechanisms through which cancer cells develop resistance to chemotherapeutic agents. The mechanisms involved in MDR include the activation of DNA repair pathways, the alteration of drug targets, as well as a decrease in the uptake of chemotherapeutic drugs (5). Drug efflux is mediated by ATP-binding cassette $(\mathrm{ABC})$ transporters, which are members of a protein superfamily that reduces intracellular drug concentrations. The upregulation of $\mathrm{ABC}$ transporter genes in cancer cells results in the active efflux of drugs, which is an important cause of MDR (6). MDR has been linked to gene amplification and/ or increased MDR1 gene expression (7). The human MDR1 
gene promoter contains a number of recognition sites for $\mathrm{SP} 1$, nuclear factor (NF)-Y, p53, NF- $\mathrm{B}$, and Y-box binding protein 1 (YB-1) transcription factors, which upregulate MDR1 promoter activity $(8-11,21)$. As regards the effect of the p53 status on the acquisition of a MDR phenotype, an inhibitory role for wild-type p53 on the MDR1 gene promoter has been demonstrated, whereas mutant p53 acts as an activator (12). Mutant p53 has been reported to upregulate $\mathrm{NF}-\kappa \mathrm{B}$ in cancer cells (13-15). The expression of mutant $\mathrm{p} 53$ and $\mathrm{NF}-\kappa \mathrm{B}$ has been found in many types of cancer with a poor prognosis $(16,17)$. $\mathrm{NF}-\kappa \mathrm{B}$ is a key transcription factor which plays a role in cancer progression and chemoresistance by ativating a multitude of mediators and processes, including cell growth, survival, transporters, anti-apoptotic genes and oncogenes (18-21). The association between the p53 status and $\mathrm{NF}-\kappa \mathrm{B}$ and their role in the development of drug resistance merits further investigation.

Epithelial-mesenchymal transition (EMT) is a process through which epithelial cells lose their cell polarity to give rise to matrix-producing fibroblasts and myofibroblasts from their neighbors and migrate to distant regions during tumor cell progression and metastasis. EMT in malignant cells is closely related to MDR (22). Transcription factors that lead to EMT and invasion orchestrate the overexpression of drug transporters by directly modulating promoter activity (23). Cadherin 1, type 1, E-cadherin (CDH1) is a suppressor of invasion and metastasis (24). The downregulation of CDH1 is considered a hallmark of EMT. Slug, a member of the Snail family of transcriptional repressors, is capable of repressing CDH1 expression and triggering EMT during malignant transformation and metastatic progression in various types of cancer (25-27). It has been demonstrated that the wild-type and mutant forms of p53 exert opposite effects on the invasion-promoting factor, Slug, to regulate cancer invasion and metastasis (26). During the development of drug resistance, the p53 status may be important for the activation of the EMT process, which mediates transformation, invasion and cancer stem cell-like properties $(28,29)$.

CD44 is a stem cell-like marker and its expression is important in the progression of many types of cancer. It has been demonstrated that CD44 plays a role in cell migration, differentiation and survival, which is important to cancer stem cells (CSCs) (30). When CD44 is highly expressed in breast cancer cells, it generates a microenvironment that facilitatestumor progression and invasion (30). It would be interesting to determine whether mutant p53 plays a role in the process through which cells acquire stem cell-like properties.

Missense mutations are the most common (75\%) of p53 mutations. Mutation hotspots may be responsible for gain-offunction effects (31). However, we have previously established a series of MCF-7 cell lines with incremental levels of resistance to doxorubicin and found that only the cell line that overexpressed the MDR1 gene contained a deleted p53 gene (Y127_K133 del p53) (32). The p53 deletion (designated as del p53) leads to increased stability, overexpression and nuclear localization of the protein. This deletion site has been found in the MCF-7/adr cell lines following different induction procedures by doxorubicin $(33,34)$. del p53 was also found in U1285 lung cancer and OVCAR-8 ovarian cancer cell lines with low levels of P-glyco protein (P-gp) $(33,35-37)$. Ribophorin II (RPN2) which is regulated by del p53 confers P-gp-mediated docetaxel resistance in MCF-7/adr cells (38). Moreover, oxidative stress-responsive heat shock factor (HSF)-1 and heat shock protein (Hsp)27 have been shown to be inhibited in mutant p53-expressing MCF-7/ adr cells, leading to increased $\mathrm{NF}-\kappa \mathrm{B}$ activity (15). Accordingly, the role of the p53 gene with a 21- (bp) deletion within the DNA binding domain warrants further investigation. The aim of this study was to examine the gain-of-resistance and metastatic properties mediated by del p53 in MCF-7 cells. Using a MCF-7 clone which stably overexpressed del p53, we examined cell proliferation, the expression levels of the genes related to drug resistance, the EMT process and stem cell-like properties.

\section{Materials and methods}

Chemicals, cell lines and cell culture. The MCF-7/adr cell line and its counterpart, MCF-7/wt, were kindly provided by Dr Chih-Hsin Yang (National Taiwan University Hospital, Taipei, Taiwan). The expression vector pcDNA3.1, pGL3Basic vector, TransFast ${ }^{\mathrm{TM}}$ Transfection reagent and GoTaq Green Master Mix were purchased from Promega Corp. (Madison, WI, USA). Lipofectamine ${ }^{\mathrm{TM}}$ 2000, TRIzol reagent, penicillin and streptomycin were purchased from Invitrogen (Carlsbad, CA, USA). G418 was purchased from Gene Teks Bioscience (New Taipei City, Taiwan). Cyclosporin A (CsA; Sandimmune) was purchased from Roche (Mannheim, Germany). 3-(4,5-Dimethylthiazol-2-yl)2,5-diphenyltetrazolium bromide (MTT) solution, verapamil, rhodamine 123 and doxorubicin were purchased from SigmaAldrich (St. Louis, MO, USA). Anti-MDR1 (SC-55510), anti-p53 (DO-1; SC-126), anti-NF-кB (p65; SC-372), and anti-mouse horseradish peroxide (HRP; SC-2005) and antirabbit peroxidase-conjugated (SC-2004) secondary antibodies were purchased from Santa Cruz Biotechnology, Inc. (Santa Cruz, CA, USA). The cells were maintained in Dulbecco's modified Eagle's medium (DMEM) with $10 \%$ fetal bovine serum (FBS) and $100 \mathrm{ng} / \mathrm{ml}$ of penicillin and streptomycin at $37^{\circ} \mathrm{C}$ in $5 \% \mathrm{CO}_{2}$. The $\mathrm{MCF}-7 /$ adr cells were grown in medium containing 6-8 $\mu \mathrm{g} / \mathrm{ml}$ of doxorubicin which was removed 1 week prior to the assays.

Construction of the plasmid pcDNA3.1 containing del p53 and the establishment of the MCF-7/del p53 cell line stably expressing del p53. Total RNA was extracted from the MCF-7/ adr cells and subjected to reverse transcription-polymerase chain reaction (RT-PCR) to yield the 21-bp-deleted p53 cDNA (del p53). Briefly, the EcoRI and KpnI restriction sites were linked onto the forward and reverse primers as follows: del p53 (EcoRI) forward, 5'-GGGAATTCATGGAGGAGCC GCAGT-3' and del p53 (KpnI) reverse, 5'-GGGGTACCGTCTGAGTCA GGCCCTT-3'. The PCR products were visualized by ethidium bromide staining, followed by double digestion with EcoRI and $K p n I$ restriction enzymes to yield a 1,104-bp fragment which was confirmed by DNA sequencing. The del p53 sequence was then inserted into the eukaryotic expression vector, pcDNA3.1, to generate a recombinant plasmid. The resulting plasmid, pcDNA3.1-del p53, was transfected into the MCF-7/wt cells, followed by the selection of stable clones containing the del p53 gene. A vector expressing C-terminal FLAG-tagged protein was constructed to confirm gene expression. Briefly, the transfection of pcDNA3.1-del p53 was carried out using Lipofectamine 2000 when the cells reached $80 \%$ cell fusion, as 
Table I. Primer sequences used for RT-PCR.

\begin{tabular}{|c|c|c|c|}
\hline Gene & & Sequence & Size (bp) \\
\hline del p53 mutant & $\begin{array}{l}\text { Forward } \\
\text { Reverse }\end{array}$ & $\begin{array}{l}\text { 5'- GAAGACCCAGGTCCAGATGA -3' } \\
\text { 5'- TGGCAAAACATCGTGCAAGTC -3' }\end{array}$ & 222 \\
\hline p53 wild-type & $\begin{array}{l}\text { Forward } \\
\text { Reverse }\end{array}$ & $\begin{array}{l}\text { 5'- GAAGACCCAGGTCCAGATGA -3' } \\
\text { 5'- CTTGTTGAGGGCAGGGGAGTA -3' }\end{array}$ & 228 \\
\hline$\beta$-actin & $\begin{array}{l}\text { Forward } \\
\text { Reverse }\end{array}$ & $\begin{array}{l}\text { 5'- ACAGCTGAGGGAAATCGTGGG -3' } \\
\text { 5'- ACTTGCGCTCAGGAGGAGCAATG -3' }\end{array}$ & 150 \\
\hline Slug & $\begin{array}{l}\text { Forward } \\
\text { Reverse }\end{array}$ & $\begin{array}{l}\text { 5'- AGATGCATATTCGGACCCAC -3' } \\
\text { 5'- CCTCATGTTTGTGCAGGAGA -3' }\end{array}$ & 257 \\
\hline Twist1 & $\begin{array}{l}\text { Forward } \\
\text { Reverse }\end{array}$ & $\begin{array}{l}\text { 5'- GGAGTCCGCAGTCTTACGAG -3' } \\
\text { 5'- TCTGGAGGACCTGGTAGAGG -3' }\end{array}$ & 201 \\
\hline Snail & $\begin{array}{l}\text { Forward } \\
\text { Reverse }\end{array}$ & $\begin{array}{l}\text { 5'- GAA AGGCCTTCAACTGCAAA -3' } \\
\text { 5'- TGACATCTGAGTGGGTCTGG -3' }\end{array}$ & 249 \\
\hline VIM & $\begin{array}{l}\text { Forward } \\
\text { Reverse }\end{array}$ & $\begin{array}{l}\text { 5'- GGAAGCTGCTGGAAGGCGA -3' } \\
\text { 5'- CCTGTCCATCTCTAGTTTCAACCGTCTTA -3' }\end{array}$ & 159 \\
\hline $\mathrm{CDH} 2$ & $\begin{array}{l}\text { Forward } \\
\text { Reverse }\end{array}$ & $\begin{array}{l}\text { 5'- AATGACAATCCTCCAGAGTTTACTGCC -3' } \\
\text { 5'- GGTGACTAACCCGTCGTTGCT -3' }\end{array}$ & 210 \\
\hline $\mathrm{CDH} 1$ & $\begin{array}{l}\text { Forward } \\
\text { Reverse }\end{array}$ & $\begin{array}{l}\text { 5'- TCACAGCAGAACTAACACACGGG -3' } \\
\text { 5'-GTGGTCACTTGGTCTTTATTCTGGTTATCC-3' }\end{array}$ & 165 \\
\hline
\end{tabular}

Primers were designed and verified using Primer3web (http://primer3.wi.mit.edu/) and on-line Primer-BLAST (http://www.ncbi.nlm.nih.gov/tools/ primer-blast/). VIM, vimentin; CDH2, cadherin 2, type 1, N-Cadherin (Neuronal); CDH1, Cadherin 1, type 1, E-cadherin.

previously described (39). DMEM (250 $\mu \mathrm{l})$ without serum and $4 \mu \mathrm{g}$ of the plasmid pcDNA3.1-del p53 per well were preincubated for 5-10 min at room temperature, followed by the addition of $10 \mu \mathrm{l}$ Lipofectamine 2000. The cells were then transfected according to the manufacturer's instructions. The successfully transfected cells were selected by $400 \mu \mathrm{g} / \mathrm{ml} \mathrm{G} 418$ gradually for 1 month to establish cell lines containing del p53 and cultured for at least 90 days to yield the stable MCF-7/del p53 cell line.

Full-length p53 cDNA sequencing. The primers used for amplifying p53 cDNA fragments and overlapping the fulllength p53 coding sequence were as follows: codons 1-148, 5'-ATGGAGGAGCCGCAGTCA-3' and 5'-ATCAACCCACA GCTGCACAGGG-3'; codons 118-353,5'-GGGACAGCCAAG TCTGTGACT-3' and 5'-CCTGGGCATCCTTGAGTT-3'; and codons 253-393, 5'-ACCATCATCACACTGGAAGACTCC-3' and 5'-ATGTCAGTCTGAGTCAGG-3'. PCR products were sequenced by Mission Biotech (Taipei, Taiwan) as previously described $(33,34)$.

Determination of gene expression by RT-PCR. Total RNA was isolated from the cells using TRIzol reagent. First strand cDNA was synthesized from the extracted RNA using an oligo(dT) primer. After the cDNA was synthesized, the primers of target genes were employed and GoTaq Green Master Mix was used to amplify the genes. The gene products were separated on a $2 \%$ agarose gel (2\% agarose/TAE buffer $100 \mathrm{ml})$. DNA was stained by ethidium bromide for $3 \mathrm{~min}$, and then detected using a UVP BioDoc-It imaging system (UVP, Inc., Upland, CA, USA). The primer sequences are listed in Table I.

MTT assay. The cells were seeded in 96-well plates at a density of $5 \times 10^{3}$ cells/well. The cytotoxicity of doxorubicin to the MCF-7/wt, MCF-7/del p53 and MCF-7/adr cells was determined by MTT assay after the cells were incubated with doxorubicin $\left(10^{-8}-10^{-4} \mathrm{M}\right)$ for 3-5 days.

Western blot analysis of $P-g p$, p53 and NF- $\mathrm{B}$. The MCF-7/ wt, MCF-7/pcDNA, MCF-7/del p53 or MCF-7/adr cells were seeded into $6-\mathrm{cm}$ plates at a density of $1 \times 10^{6}$ cells/well. Following incubation for 2 days, total protein was isolated using RIPA cell lysis buffer, containing $150 \mathrm{mM} \mathrm{NaCl}, 1.0 \%$ (v/v) Triton X-100, 0.5\% (v/v) sodium deoxycholate, $0.1 \%$ (w/v) SDS and $50 \mathrm{mM}$ Tris ( $\mathrm{pH} 8.0$ ). Protein concentrations were determined using a Bradford assay with the Bio-Rad protein assay kit (Richmond, CA, USA). Protein samples were loaded onto a $10 \%$ SDS-polyacryamide gel, and then transfered onto an Immobilon NC membrane (Millipore Corp., Bedford, MA, USA) with transfer buffer [25 mM Tris, $190 \mathrm{mM}$ glycine, $20 \%(\mathrm{v} / \mathrm{v})$ methanol]. The membranes were then blocked in 5\% milk TBST (Tris-buffered saline Tween-20) at room temperature for $1 \mathrm{~h}$. Proteins were labeled with anti-MDR1, anti-p53 (DO-1) and anti-NF- $\mathrm{B}$ (p65) antibodies. The p53 antibody (DO-1) was used for the detection of wild-type and mutant p53 by epitope mapping of amino acid residues 11-25 of p53. Immunoreactive bands were detected by anti-mouse HRP or anti-rabbit peroxidase-conjugated secondary antibody. 
Protein bands were visualized using an enhanced chemiluminescence (ECL) detection kit (GE Healthcare, Little Chalfont, UK) and detected using a UVP BioDoc-IT imaging system.

Construction of the expression vector containing the MDRI promoter. The sequences of the primers used for plasmid construction are as follows: primer 1,5'-GCGCTAGCCTAGA GAGGTGCAACG-3' (-198 to -182); primer 2, 5'-GCAGATCT GCGGCCTCTGCTTCTT-3' (+28 to +43). The 241-bp MDR1 promoter fragment (residues -198 to +43 ) was amplified by PCR using primers 1 and 2. The pGL3-Basic vector was digested with NheI and $B g l I I$. The gel-purified PCR product was digested with NheI and $B g l I I$ and cloned into the vector, as previously described (40). The accuracy of the pGL3-promoter vector was confirmed by direct sequencing.

Transient expression assay. The cells $\left(3 \times 10^{5}\right.$ cells/well) were seeded into 6-well plates and grown in $5 \mathrm{ml}$ of DMEM with $10 \%$ FCS for $24 \mathrm{~h}$ prior to transfection. Using TransFast Transfection reagent, the cells were transfected with $2 \mu \mathrm{g} / \mathrm{well}$ plasmid. Luciferase activity was measured using a Bright-Glo Luciferase Assay system (Promega Corp.). Luminescence was measured using a Berthold Microplate Luminometer (Berthold Technologies GmbH, Bad Wildbad, Germany).

Determination of drug efflux by flow cytometric analysis. The cells were pre-treated with or without $4 \mu \mathrm{M}$ of the P-gp inhibitor, verapamil, for $2 \mathrm{~h}$. The cells were then incubated with $10 \mu \mathrm{M}$ rhodamine 123 in the dark at $37^{\circ} \mathrm{C}$ for $1 \mathrm{~h}$ and were then trypsinized from the subfluent monolayer, and the pellet was washed twice with ice-cold PBS. Rhodamine 123 accumulation in the cells was analyzed immediately using a FACSCaliber flow cytometer (BD Biosciences San Jose, CA, USA). The fluorescence of rhodamine 123 was measured using a FL1 band-pass filter.

Wound healing assay. The cells in medium containing $10 \%$ FBS were seeded into 24-multiwell plates. After the cells grew to confluence, wounds were made using sterile pipette tips. The cells were washed with PBS and refreshed with medium with or without $10 \%$ FBS. Following overnight incubation at $37^{\circ} \mathrm{C}$, the cells were photographed using a Nikon Coolpix 995 digital camera (Nikon Corp., Tokyo, Japan). The migration distances were quantified by Inage $\mathrm{J}$ software which is a Java-based image analysis package.

Flow cytometric analysis of the CSC markers, CD44 and CD24. The MCF-7 cells were analyzed after staining with CD24-PE (Cat. no. 555428) or CD44-FITC (Cat. no. 555478) antibody that were purchased from BD Pharmingen (San Diego, CA, USA). At least $1 \times 10^{5}$ cells were centrifuged at $500 \mathrm{xg}$ for $3 \mathrm{~min}$ at $4^{\circ} \mathrm{C}$, resuspended in $10 \mu \mathrm{l}$ of FITC-conjugated anti-CD44 and $10 \mu \mathrm{l}$ of PE-conjugated anti-CD24, and then incubated at $4^{\circ} \mathrm{C}$ in the dark for $30 \mathrm{~min}$. As a negative control, cells were incubated with the isotype of CD44 or CD24. The labeled cells were washed 3 times and then analyzed using a FACSCaliber flow cytometer (BD Biosciences). Each analysis detected 10,000 cells.

Colony formation assay. The cells $\left(5 \times 10^{3}\right)$ in $1.5 \mathrm{ml}$ $0.35 \%$ agarose-containing growth medium were overlaid with

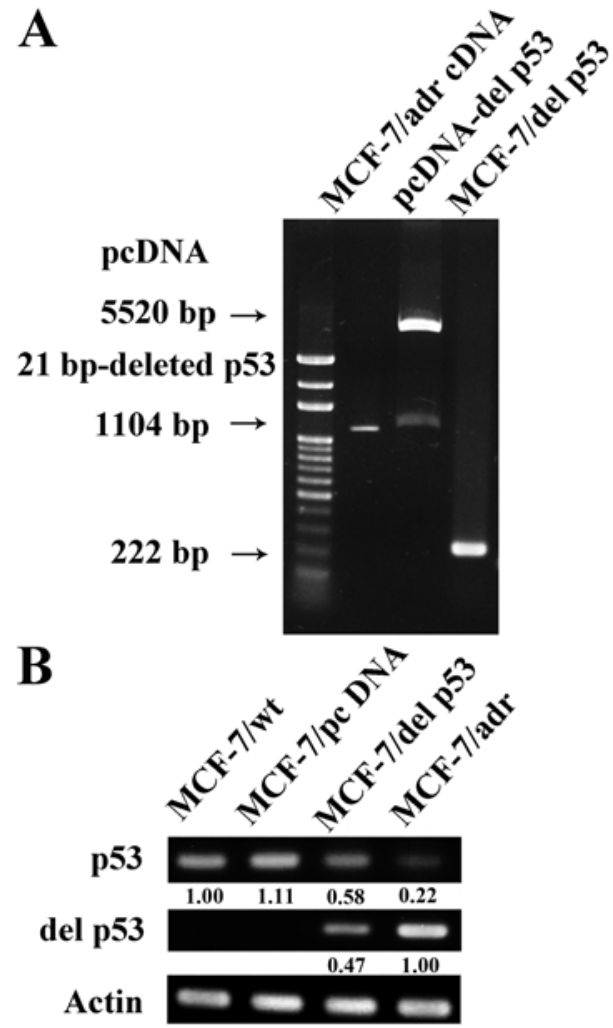

Figure 1. Cloning of MCF-7/del p53 cell line stably expressing del p53. (A) Detection of del p53 cDNA in the cloning of MCF-7/del p53. The fulllength del p53 cDNA from MCF-7/adr cells and pcDNA-del p53 vector were restricted by $E c o$ RI and $K p n I$ to yield a 1,104-bp fragment. A 222-bp cDNA fragment from the MCF-7/del p53 stable clone was produced using RT-PCR with a pair of del p53 primers. The DNA fragments were electrophoresized on a $2 \%$ agarose gel. (B) del p53 was stably expressed in MCF-7/del p53. mRNA levels were determined in MCF-7/wt, MCF-7/del p53, MCF-7/adr cells using semi-quantitative RT-PCR, and followed by $2 \%$ agarose gel electrophoresis. mRNA in MCF-7/pcDNA was used as the control.

$1.5 \mathrm{ml} 0.5 \%$ agarose-containing growth medium, and the cells were incubated for 10-14 days. The whole-well images were photographed using a Nikon Coolpix 995 digital camera (Nikon Corp.) and 3 fields (x10 magnification) of each well were imaged.

Statistical analysis. Data are statistically presented as the means \pm SEM for the indicated number of separate experiments. Comparisons between groups were made using Student's t-tests. Probability values of $\mathrm{P}<0.05$ were considered to indicate statistically significant differences.

\section{Results}

Establishment of the MCF-7/del p53 cell line stably expressing del p53. Total RNA was extracted from the MCF-7/adr cells and subjected to RT-PCR to yield a 1,104-bp full-length mutant p53 cDNA, designated as del p53. del p53 was then inserted into the eukaryotic expression vector, pcDNA3.1. The resulting plasmid, pcDNA3.1-del p53, was transfected into the MCF-7/ wt cells, and this was followed by selection of stable clones containing the del p53 gene which was confirmed by a 222-bp RT-PCR product (Fig. 1A). The MCF-7/del p53 cell line is one of the stable clones with similar characteristics. DNA sequencing 


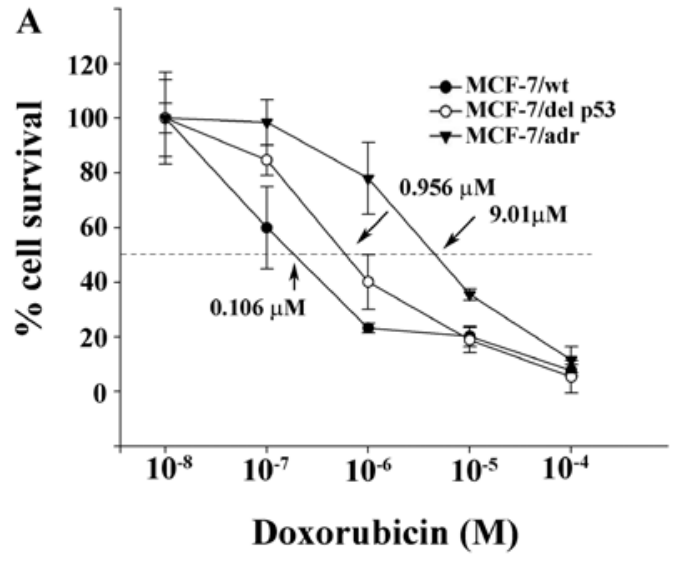

B

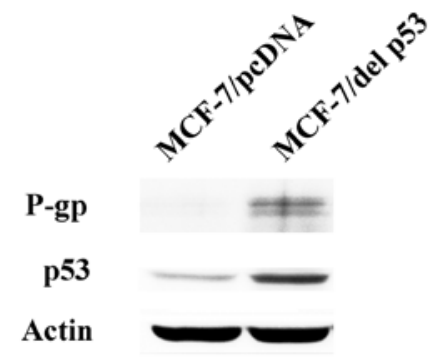

Figure 2. MCF-7/del p53 cells acquire resistance to doxorubicin. (A) MCF-7/del p53 gained resistance to doxorubicin. Cell survival was assayed in MCF-7/wt, MCF-7/del p53 and MCF-7/adr cells by MTT assay. Untreated cells were used as a control and each treatment was performed in triplicate wells. Data are expressed as the means \pm SEM of 3 separate experiments $(n=3)$. (B) Expression of P-glycoprotein (P-gp) and p53 protein in MCF-7/del p53 cells. Proteins were extracted from pcDNA-del p53 and MCF-7/pcDNA and were subjected to electrophoresis followed by western blot analysis. p53 protein was detected by p53 antibody DO-1 against wild-type p53 and del p53.

was performed to confirm a 21-bp deletion of p53 in the MCF-7/ adr and MCF-7/del p53 cells. We then determined the mRNA expression levels of p53 in the various cell lines by RT-PCR. MCF-7/wt did not express del p53 mRNA, whereas the MCF-7/ del p53 cells stably expressed both wild-type p53 and del p53 mRNA (Fig. 1B). The expression level of the del p53 gene in the MCF-7/del p53 cells was approximately $47 \%$ lower than the level in the MCF-7/adr cells.

MCF-7/del p53 cells acquire resistance to doxorubucin. In our previous study, the mutant p53 gene with a 21-bp deletion was detected in doxorubicin-resistant MCF-7 cell lines following various induction processes (32). In this study, we wished to examine the role of del p53 in the acquired resistance of MCF-7 cells to doxorubicin. The degree of resistance to doxorubicin was assessed by MTT assay in the MCF-7/wt, MCF-7/del p53 and MCF-7/adr cells. The concentrations of doxorubicin that inhibited cell survival by $50 \%\left(\mathrm{IC}_{50}\right)$ were extrapolated from cell survival plots. The $\mathrm{IC}_{50}$ values in the MCF-7/wt, MCF-7/ del p53 and MCF-7/adr cells were 0.106, 0.956 and $8.179 \mu \mathrm{M}$, respectively (Fig. 2A). The resistance index is defined as the ratio of the $\mathrm{IC}_{50}$ value of $\mathrm{MCF}-7 / \mathrm{del}$ p53 or MCF-7/adr to the $\mathrm{IC}_{50}$ value of $\mathrm{MCF}-7 / \mathrm{wt}$. Accordingly, the resistance indexes of the MCF-7/adr and MCF-7/del p53 cells are 77.16 and 9.01, respectively, compared with the MCF-7/wt cells. The acquisition of resistance to doxorubicin may be related to the transfection of del p53 into the MCF-7 cells. The gain- of-resistance activity may be associated with the capability of del p53 to stimulate the expression of an alternate set of endogenous genes that potentially promotes tumor progression and induces drug resistance. The expression of the MDR1 gene was also examined to examine the hypothesis that MDR1 is the endogenous target of del p53 and that the activation of MDR1 is mediated by del p53. Western blot analysis revealed that the p53 protein was detected by the antibody against both wildtype p53 and del p53 in the MCF-7/del p53 cells, whereas only low levels of p53 protein were detected in the MCF-7/pcDNA control. It is probable that the del p53 protein, with a longer half-life compared with wild-type p53, was stably expressed in the MCF-7/del p53 cells (Fig. 2B). The MDR marker, P-gp, was also mildly expressed in the MCF-7/del p53 cells. The low level of P-gp was consistent with the degree of the increase in the resistance index of MCF-7/del p53 cells.

del p53-mediated P-gp function is associated with MDRI promoter activation and $N F-\kappa B$ expression. To examine the positive role of del p53 on the MDR1 promoter in MCF-7 cells, we inserted the MDR1 promoter (residues -198 to $+43,241 \mathrm{bp}$ ) into a luciferase-expressing pGL3-basic vector upstream of the luciferase gene to generate the pGL3-MDR vector. The cells were transiently transfected with pGL3-MDR. The activity of the MDR1 promoter was measured as a function of luciferase. Luciferase activity in the MCF-7/del p53 and MCF-7/adr cells was significantly higher than that in the MCF-7/wt cells (Fig. 3A). To rule out the interaction of other endogenous factors with possible regulatory sites on the MDR1 promoter region in pGL3-MDR, the MCF-7/wt cells were co-transfected with the pGL3-MDR and pcDNA3.1-del p53 vector. A high luciferase activity was also observed in the co-transfected cells. It is probable that the del p53 protein contributed to the activation of the MDR1 promoter and its downstream genes. We then assessed intracellular rhodamine 123 accumulation, to determine whether the P-gp efflux function was enhanced by del p53 protein. The results revealed a moderate decrease in rhodamine 123 accumulation in the MCF-7/del p53 cells compared with the MCF-7/ wt cells (Fig. 3B). By adding the P-gp inhibitor, verapamil, the intracellular rhodamine 123 level was restored in the MCF-7/ del p53 cells. As the degree of MDR1 promoter activation is not projected to the P-gp efflux function in MCF-7/del p53, we hypothesized that additional factors may be required for P-gp expression and function. The ubiquitous transcription factor, $\mathrm{NF}-\kappa \mathrm{B}$, controls the expression of numerous genes in apoptotic pathways and induces drug resistance in cancer cells (21). Thus, to determine whether del p53 protein expression is in accordance with the increase in $\mathrm{NF}-\kappa \mathrm{B}$, the $\mathrm{NF}-\kappa \mathrm{B}$ protein levels were measured by western blot analysis. The results revealed that the NF- $\kappa \mathrm{B}$ and P-gp levels were moderately increased in the MCF-7/del p53 cells in comparison with the parent MCF-7/wt cells (Fig. 3C). This increase in expression was suppressed by treatment with the $\mathrm{NF}-\kappa \mathrm{B}$ inhibitor, CsA. Cell survival assays demonstrated that the addition of CsA sensitized the MCF-7/ del p53 and MCF-7/adr cells to doxorubicin toxicity (Fig. 3D). Thus, P-gp expression may involve the upregulation of NF- $\kappa \mathrm{B}$ in MCF-7/del p53 cells.

EMT is induced in MCF-7/del p53 cells. We examined cellular changes, including morphology and EMT markers, that may 

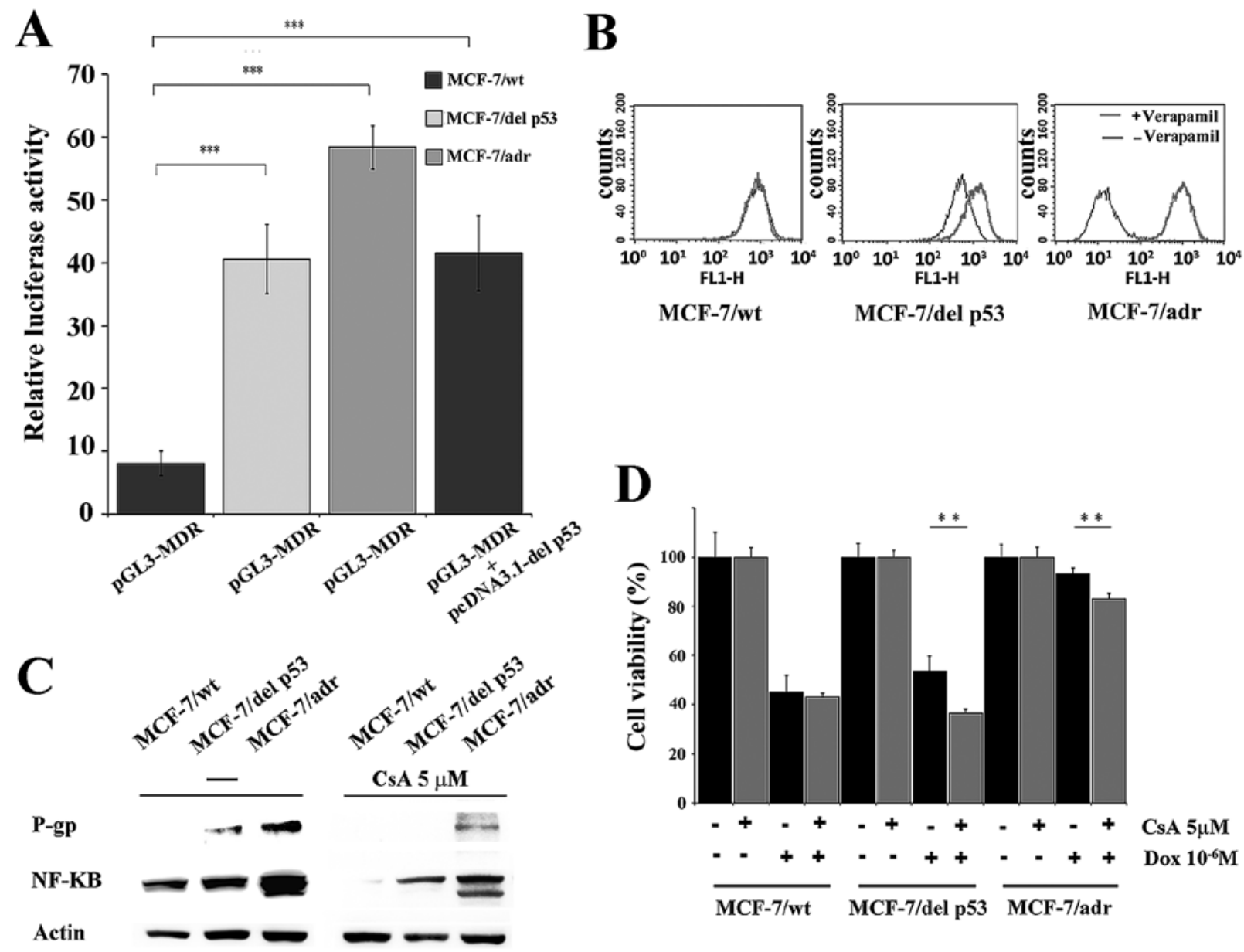

Figure 3. del p53-mediated P-glycoprotein (P-gp) function is associated with MDR1 promoter activation and nuclear factor (NF)- $\mathrm{kB}$ expression. (A) MDR1 promoter is activated by del p53. Activation of MDR1 promoter was determined by luciferase activity using transient expression assay in MCF-7/wt, MCF-7/ del p53, MCF-7/adr and MCF-7/wt cells with co-transfection of pcDNA3.1-del p53. Data are expressed as the means \pm SEM of 3 separate experiments (n=3). ${ }^{* * *} \mathrm{P}<0.001$. (B) MCF-7/del p53 cells had lesser rhodamine 123 accumulation. P-gp efflux was determined in MCF-7/wt, MCF-7/del p53 and MCF-7/adr cells. The cells were incubated with rhodamine 123 alone (black) or with additional verapamil $10 \mu \mathrm{M}$ (gray) for $1 \mathrm{~h}$. A rhodamine accumulation assay using flow cytometry was then performed. (C) Expression of P-gp was diminished when NF- $\kappa$ B was inhibited by cyclosporine (CsA) in MCF-7/del p53. MCF-7/wt, MCF-7/del p53 and MCF-7/adr were treated with or without $5 \mu \mathrm{M}$ CsA for $72 \mathrm{~h}$. P-gp and NF- $\kappa B$ expression was detected by western blot analysis. (D) NF- $\kappa \mathrm{B}$ inhibition decreased the resistance to doxorubicin in MCF-7/del p53 and MCF-7/adr cells. MCF-7/wt, MCF-7/del p53 and MCF-7/adr cells were treated wit $10^{-6} \mathrm{M}$ doxorubicin or $5 \mu \mathrm{M}$ CsA alone or in combination for $72 \mathrm{~h}$. Untreated cells were used as the control. Cell viability was assayed by an MTT assay. Data are expressed as the means \pm SEM of 3 separate experiments $(n=3) .{ }^{* *} \mathrm{P}<0.01$.

be mediated by del p53 in MCF-7/del p53 cells. The MCF-7/wt cells were arranged in a tightly-packed layer, which is characteristic of epithelial cells and exhibited limited cell spreading. Unlike the MCF-7/wt cells, the MCF-7/del p53 cells had a flattened morphology and had lost cell-cell contacts, which was similar to the MCF-7/adr cells (Fig. 4A). Changes in the morphological characteristics of epithelial cells may lead to the cells losing their epithelial characteristics and can increase their metastatic and invasive potential (41). The induction of EMT leads to the acquisition of mesenchymal traits (42). In this study, the expression of a series of EMT-related transcription factors was determined by RT-PCR. The expression of mesenchymal markers was upregulated, including that of Slug and vimentin in the MCF-7/del p53 cells, and the expression of the epithelial marker, CDH1, was downregulated (Fig. 4B). However, the mesenchymal marker, $\mathrm{CDH} 2$, was not observed in the MCF-7/del p53 cells. The overexpression of EMT-inducing transcription factors has been associated with chemoresistance and the depletion of these factors has been shown to increase drug sensitivity (23). Thus, we wished to determine whether the upregulation of the transcription factors, Slug and vimentin, enhances the invasive ability of the MCF-7/del p53 cells. The results of wound healing assay demonstrated that the migration ability of the MCF-7/del p53 cells increased by 2.5 -fold, compared with the MCF-7/wt cells (Fig. 4C and D). The longer migration distances may be due to the activation of the mesenchymal markers in the MCF-7/del p53 cells.

MCF-7/del p53 cells exhibit CSC-like properties. Alterations in CD44/CD24 configuration are associated with human breast CSCs and normal mammary epithelial stem cells. When CD44 is highly expressed in breast cancer cells, it generates a microenvironment to facilitate tumor progression and invasion (30). Thus, we detected the CD44/CD24 subpopulations in MCF-7/del p53 cells by flow cytometry. As shown by our results, the MCF-7/wt cells exhibited a CD44 ${ }^{\text {low }}$ subpopulation, 

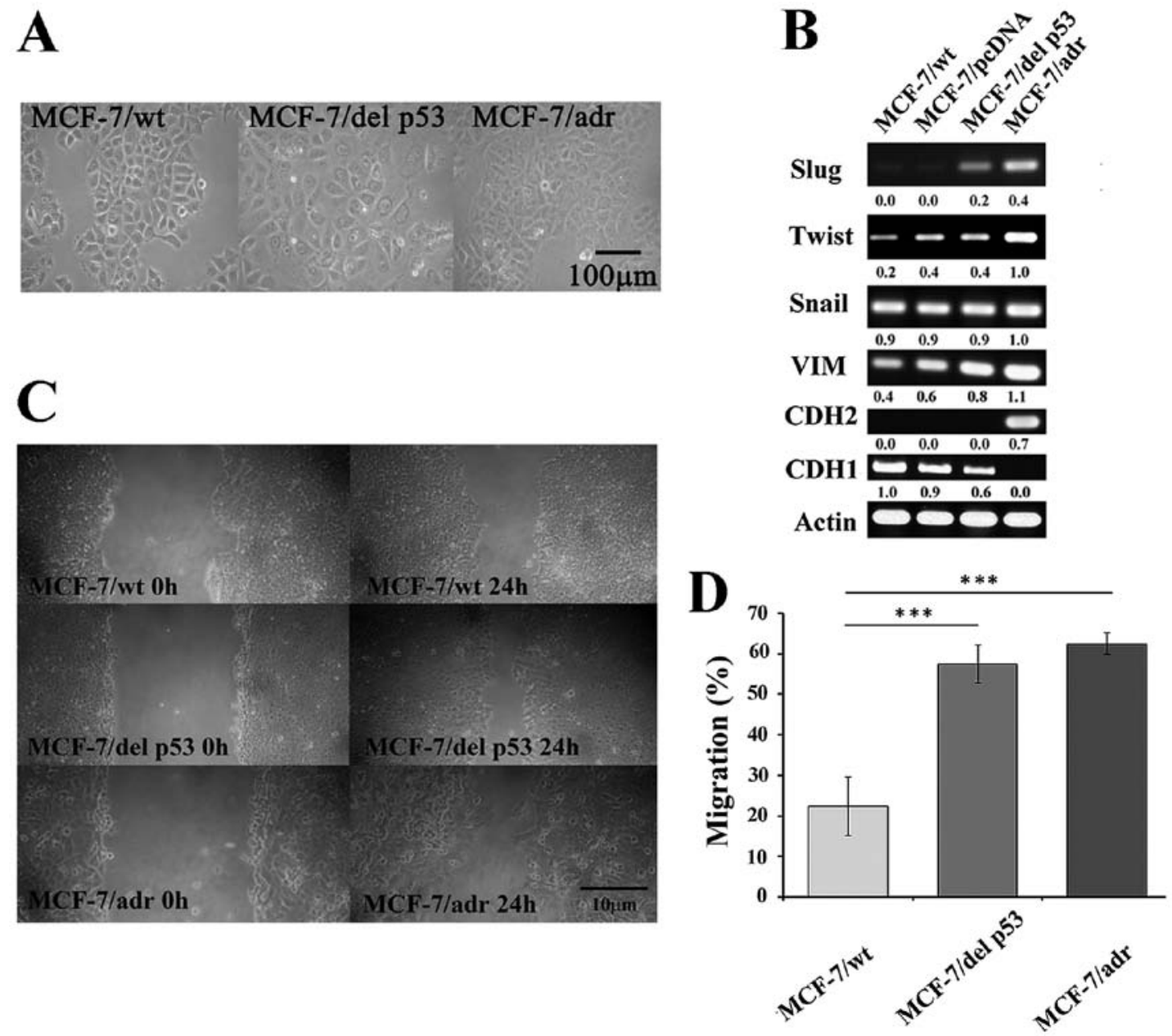

Figure 4. del p53 is involved in the EMT process. (A) Phase-contrast microscopic images of MCF-7/wt, MCF-7/del p53 and MCF-7/adr cells (x200 magnification), scale bar, $100 \mu \mathrm{m}$. (B) Expression of EMT-related transcription factors Slug, Twist, Snail, VIM, CDH1 and CDH2. RT-PCR products were run on a $1 \%$ agarose gel to show the expression levels of transcription factors. (C) Photomicrographs show cell migration by wound healing assay. (D) Graph represents relative cell migration distances measured at 0 and $24 \mathrm{~h}$ in MCF-7/wt, MCF-7/del p53 and MCF-7/adr cells, using Image $\mathrm{J}$ software, $\mathrm{n}=3$. Error bars denote \pm SEM. ${ }^{* * * *} \mathrm{P}<0.001$.

whereas the MCF-7/adr cells exhibited a CD44high $/ \mathrm{CD} 24^{\text {high }}$ subpopulation. The MCF-7/del p53 cells were thus in a transitional phase, exhibiting an increase in the $\mathrm{CD} 44^{\text {high }} / \mathrm{CD} 24^{\text {high }}$ subpopulation (Fig. 5A). The number of colonies formed in the MCF-7/del p53 cells was 5.7-fold higher than that in the MCF-7/ wt cells (Fig 5B and C).

\section{Discussion}

It is well known that p53, which is involved in DNA repair, plays an important role in the maintenance of genome integrity in response to a variety of anticancer drugs (43). Mutations in p53 are linked with the defects in growth arrest, apoptosis after DNA damage and sensitivity to anticancer agents (44). Mutant p53 not only disrupts sequence-specific transactivation, but also confers gain-of-function effects, such as the overexpression of the drug resistance gene, MDR1, in tumors $(12,45)$. Wildtype 533 has an inhibitory effect on the MDR1 gene promoter, whereas mutant p53 disrupts the DNA binding domain and acts as an activator (12). Transcription factors, such as NF- $\kappa \mathrm{B}, \mathrm{SP1}$, NF-Y, C/EBP- $\beta$ and activator protein (AP)-1, bind to the MDR1 promoter to regulate MDR1 gene expression in a complex manner, since transcription factors may act through competi- tive or cooperative interactions with the MDR1 promoter (46). Mutant p53 directly binds to the MDR1 promoter to transactivate MDR1 expression or indirectly interact with other transcription factors, such the proto-oncogenic factor ETS-1, to modulate MDR1 expression. The results from the present study demonstrated a high transient expression of the MDR1 promoter in MCF-7/del p53 or MCF-7/wt cells co-transfected with the MDR1 promoter and del $\mathrm{p} 53$, indicating that MDR1 promoter activity is exclusively mediated by either internal or external del p53. Other possible factors acting on the regulatory sites in our pGL3-MDR construct were ruled out. Increased MDR1 expression is mediated by mutated p53 in a variety of cancer cell lines. In Caco-2 cells, the MDR1 promoter was activated by p53 mutants at R175H and D281G, whereas wild-type p53 had either no effect or an inhibitory effect on the promoter (12). In Saos-2 cells, the MDR1 promoter was activated by p53 mutants at R175H and R248Q (47). In Hep3B cells, p53 mutants at R248Q and R273C activated the MDR1 promoter (48). Mutant p53 with a 21-bp deletion in exon 5 has been found in MCF-7/adr cells, as well as in U1285 and OVCAR-8 cells $(33,35,36)$. High levels of P-gp have been found in MCF-7/adr cells, whereas low levels of P-gp have been detected in U1285 and OVCAR- 8 cells $(36,49)$. MCF-7/del p53 cells also weakly expressed P-gp in our study. 

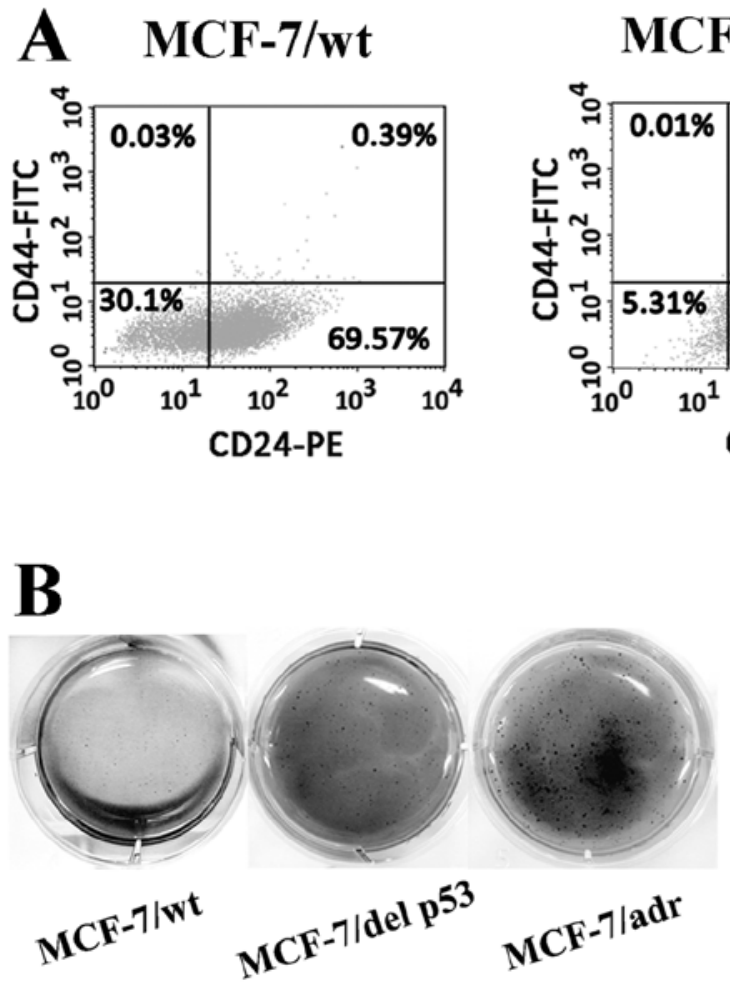

MCF-7/del p53

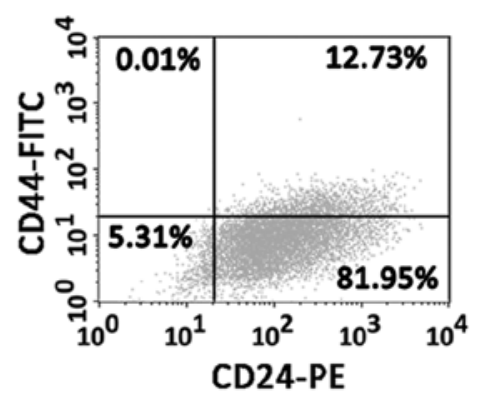

MCF-7/adr

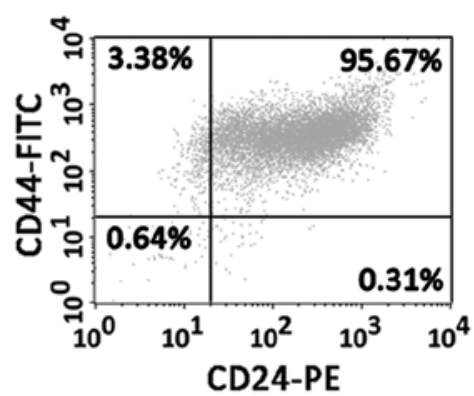

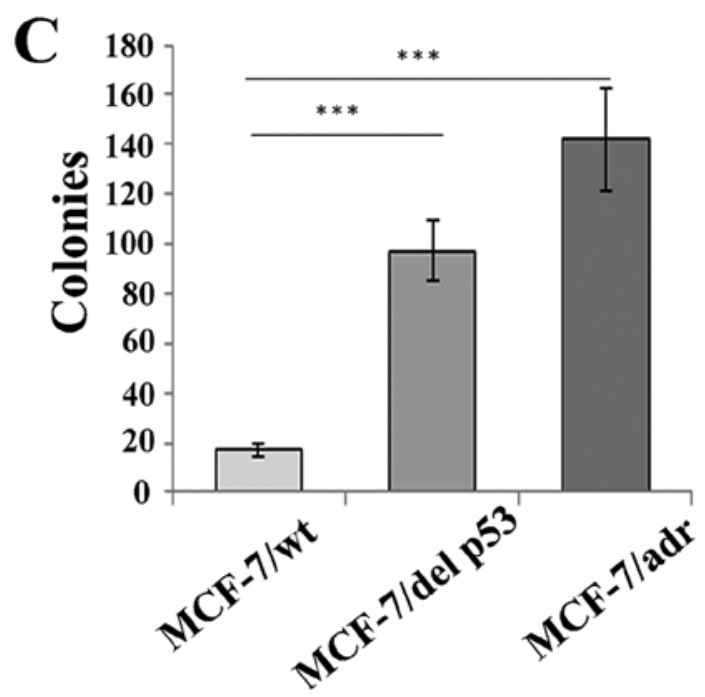

Figure 5. MCF-7/del p53 cells acquire cancer stem cell (CSC)-like properties. (A) Graphs of stem cell-like surface markers CD44/CD24 distribution in MCF-7/wt, MCF-7/del p53 and MCF-7/adr cells. Fluorescence-activated cell sorting was performed using surface antigens for CD44-FITC and CD24-PE. The cells were gated with isotype controls. (B) Colony formation in 3-dimensional cultures. MCF-7/wt, MCF-7/del p53 and MCF-7/adr cells were grown in soft agar to form mammospheres. (C) Colony formation assay. The number of colonies is indicated in $2 \times 10^{3}$ plated cells. Quantification and statistical analysis are expressed as the means \pm SEM of 3 separate experiments $(\mathrm{n}=3) .{ }^{* * *} \mathrm{P}<0.001$.

This implies that, in addition to del p53, other factors may be recruited to accomplish P-gp expression and induce MDR. The transfection of NF- $\mathrm{KB}$ has been reported to induce P-gp expression (50). In a previous study, NF- $\kappa B$-induced drug resistance was suppressed by the NF- $\mathrm{KB}$ inhibitor, CsA, through decreased P-gp expression (21). Our results revealed a higher level of NF- $\mathrm{KB}$ expression in MCF-7/del p53 cells. This expression was suppressed by CsA, and accompanied by a diminished P-gp expression. In this way, the MCF-7/del p53 cells were significantly sensitized to doxorubicin toxicity. We therefore hypothesized that the activation of the MDR1 promoter by del p53 may be partly related to the upregulation of NF- $\mathrm{kB}$. It is possible that del p53 is an important upstream factor for NF- $\mathrm{kB}$ activation which aids the aggressive growth and drug resistance of cancer cells. However, the fact that CsA exerted less of an inhibitory effect on cell survival in MCF-7/adr cells, compared with that in MCF-7/del p53 cells, illustrates that complex factors are involved in the acquisition of drug resistance.

EMT is considered an essential process in the metastatic cascade. The loss of epithelial markers, including CDH1, ZO-1, occludin, as well as a corresponding increase in mesenchymal markers, such as vimentin, Slug, SMA, fibronectin and $\mathrm{CDH} 2$, are critical events signaling the loss of the epithelial phenotype and the commencement of mesenchymalization (24). Usually, the EMT process is mediated by the inhibition of $\mathrm{CDH} 1$ expression, leading to the induction of $\mathrm{CDH} 2$ expression, and this has been associated with tumor invasiveness and CSC-like properties. EMT transcription factors, such as Twist, Snail and Slug, play a regulatory role repressing $\mathrm{CDH} 1$ gene expression. The expression of Slug is associated with MDR $(22,51)$. Emerging evidence has suggested that mutant p53 induces drug resistance and mediates invasiveness through the positive regulation of Slug, an invasion-promoting factor in EMT (26). The aberrant expression of Slug also contributes to the invasive behavior of glioma and melanoma cells $(25,52)$. Yet, little is known about the molecular mechanisms of mutant p53 linking the two phenomena. The present study found that the transcription factors, Slug and vimentin, were upregulated and CDH1 was downregulated in the MCF-7/del p53 cells. In addition, gain of oncogenic function by p53 mutants has been shown to regulate EMT-related gene expression in colon and endometrial cancers $(29,53)$. The expression of Slug has also been shown to contribute to cisplatin resistance in ovarian cancer and to activate the transforming growth factor $\beta$ signaling pathway in MCF-7 cells $(54,55)$. However, in this study, the ultimate mesenchymal marker, $\mathrm{CDH} 2$, which is a key factor for the commencement of the EMT process was not detected in the MCF-7/del p53 cells. Moreover, unlike the MCF-7/adr cells with no $\mathrm{CDH} 1$ expression, the MCF-7/del p53 cells still presented with low levels of $\mathrm{CDH} 1$. This indicates that the 21-bp-deleted 
p53 may participate in the initiation of EMT, although the subsequent recruitment of additional factors is necessary for the upregulation of $\mathrm{CDH} 2$ expression. The identity of the additional factors remains unknown. As previousy demonstrated, the mouse double minute 2 homolog (MDM2)-mediated degradation of Slug may be inhibited by mutant p53 to result in cancer cell invasion (26). However, further investigations are warranted.

The induction of an EMT in immortalized human mammary epithelial cells result in not only the acquisition of mesenchymal traits, but also increases the expression of stemcell markers. Slug is involved in MDR which is mediated by stem cell factor (SCF)/c-Kit in malignant mesothelioma cells. Slug gene expression is also part of a hypoxia-induced genetic program which sets up a basal/stem cell-like, aggressive phenotype in breast cancer cells $(27,56)$. CD44 is a cell surface marker that is expressed in the progression of many tumors, as well as in CSCs. The overexpression of EMT-related genes, such as Slug and Gli-2, can transform MCF-7 cells from a CD $44^{\text {low }} / \mathrm{CD} 24^{\text {high }}$ phenotype to the stem cell-like properties of a CD $44^{\text {high }} / \mathrm{CD} 24^{\text {low }}$ phenotype $(30,57)$. Our data demonstrated a transitional manner of CD44/CD24 configuration in MCF-7/ del p53 cells compared with the CD $44^{\text {high }} / \mathrm{CD} 24^{\text {high }}$-enriched MCF-7/adr cells and the CD44 ${ }^{\text {low }}$-enriched MCF-7/wt cells. This indicated that the cell subpopulations of MCF-7/del p53 shifted to CSC-like cells.

The cell migration ability of the MCF-7/del p53 cells was significantly greater than that of the MCF-7/wt cells, indicating that 21-bp-deleted p53 may enable the cells to acquire CSC-like properties. Breast cancers are classified into luminal, basal, mesenchymal, ErbB2-positive and myoepithelial, according to molecular profiling studies. Cell lines that contain CD $44^{\text {high }} / \mathrm{CD} 241^{\text {ow }}$ populations are in the basal /mesenchymal or the myoepithelial group (58-60). In this regard, the co-existence of aberrant Slug and CD $44^{\text {high }}$ markers suggests that MCF-7/del p53 cells may emerge through an EMT process in which the cells lose their epithelial characteristics and gain mesenchymal properties, and then progress toward an MDR phenotype. Further studies are required in order to provide the necessary evidence.

In conclusion, 21-bp-deleted p53 found in a variety of cancer cells is a gain-of-function mutation which partly participates in the acquisition of chemoresistance in MCF-7 cells. The underlying mechanisms involve the transactivation of the MDR1 promoter through NF- $\kappa \mathrm{B}$ upregulation, the increased expression of the mesenchymal markers, Slug and vimentin, as well as the stem cell-like marker, CD44, in MCF-7 cells stably expressing 21-bp-deleted p53. Thus, the 21-bp deletion of p53 has potential for use as a therapeutic target with which to inhibit gain-of-resistance in cancers.

\section{Acknowledgements}

This study was supported by a grant from the Taiwan Cancer Foundation (no. TCF101-TM02-B4).

\section{References}

1. Muller PA and Vousden KH: p53 mutations in cancer. Nat Cell Biol 15: 2-8, 2013.
2. Petitjean A, Achatz MI, Borresen-Dale AL, Hainaut P and Olivier M: TP53 mutations in human cancers: functional selection and impact on cancer prognosis and outcomes. Oncogene 26: 2157-2165, 2007.

3. Keshelava N, Zuo JJ, Waidyaratne NS, Triche TJ and Reynolds CP: p53 mutations and loss of p53 function confer multidrug resistance in neuroblastoma. Med Pediatr Oncol 35: 563-568, 2000.

4. Sturm I, Bosanquet AG, Hermann S, Güner D, Dörken B and Daniel PT: Mutation of p53 and consecutive selective drug resistance in B-CLL occurs as a consequence of prior DNA-damaging chemotherapy. Cell Death Differ 10: 477-484, 2003.

5. Pritchard JR,Lauffenburger DA and Hemann MT: Understanding resistance to combination chemotherapy. Drug Resist Updat 15: 249-257, 2012.

6. Glavinas H, Krajcsi P, Cserepes J and Sarkadi B: The role of ABC transporters in drug resistance, metabolism and toxicity. Curr Drug Deliv 1: 27-42, 2004.

7 Warmann S, Hunger M, Teichmann B, Flemming P, Gratz KF and Fuchs J: The role of the MDR1 gene in the development of multidrug resistance in human hepatoblastoma: clinical course and in vivo model. Cancer 95: 1795-1801, 2002.

8. Bargou RC, Jürchott K, Wagener C, Bergmann S, Metzner S, Bommert K, Mapara MY, Winzer KJ, Dietel M, Dörken B and Royer HD: Nuclear localization and increased levels of transcription factor YB-1 in primary human breast cancers are associated with intrinsic MDR1 gene expression. Nat Med 3: 447-450, 1997.

9. Chin KV, Ueda K, Pastan I and Gottesman MM: Modulation of activity of the promoter of the human MDR1 gene by Ras and p53. Science 255: 459-462, 1992.

10. Okamura H, Yoshida K, Sasaki E, Morimoto H and Haneji T: Transcription factor NF-Y regulates mdr1 expression through binding to inverted CCAAT sequence in drug-resistant human squamous carcinoma cells. Int J Oncol 25: 1031-1037, 2004.

11. Rohlff $C$ and Glazer RI: Regulation of the MDR1 promoter by cyclic AMP-dependent protein kinase and transcription factor Sp1. Int J Oncol 12: 383-386, 1998.

12. Sampath J, Sun D, Kidd VJ, Grenet J, Gandhi A, Shapiro LH, Wang Q, Zambetti GP and Schuetz JD: Mutant p53 cooperates with ETS and selectively up-regulates human MDR1 not MRP1. J Biol Chem 276: 39359-39367, 2001.

13. Arlt A and Schäfer H: NFkappaB-dependent chemoresistance in solid tumors. Int J Clin Pharmacol Ther 40: 336-347, 2002.

14. Deb D, Scian M, Roth KE, Li W, Keiger J, Chakraborti AS, Deb SP and Deb S: Hetero-oligomerization does not compromise 'gain of function' of tumor-derived p53 mutants. Oncogene 21: 176-189, 2002.

15. Kanagasabai R, Krishnamurthy K, Druhan LJ and Ilangovan G: Forced expression of heat shock protein 27 (Hsp27) reverses P-glycoprotein (ABCB1)-mediated drug efflux and MDR1 gene expression in Adriamycin-resistant human breast cancer cells. J Biol Chem 286: 33289-33300, 2011.

16. Cooks T, Pateras IS, Tarcic O, Solomon H, Schetter AJ, Wilder S, Lozano G, Pikarsky E, Forshew T, Rosenfeld N, et al: Mutant p53 prolongs $\mathrm{NF}-\kappa \mathrm{B}$ activation and promotes chronic inflammation and inflammation-associated colorectal cancer. Cancer Cell 23: 634-646, 2013.

17. Ferris RL and Grandis JR: NF-kappaB gene signatures and p53 mutations in head and neck squamous cell carcinoma. Clin Cancer Res 13: 5663-5664, 2007.

18. Li Y, Ahmed F, Ali S, Philip PA, Kucuk O and Sarkar FH: Inactivation of nuclear factor kappaB by soy isoflavone genistein contributes to increased apoptosis induced by chemotherapeutic agents in human cancer cells. Cancer Res 65: 6934-6942, 2005.

19. Braeuer SJ, Büneker C, Mohr A and Zwacka RM: Constitutively activated nuclear factor-kappaB, but not induced NF-kappaB, leads to TRAIL resistance by up-regulation of X-linked inhibitor of apoptosis protein in human cancer cells. Mol Cancer Res 4: 715-728, 2006.

20. Godwin P, Baird AM, Heavey S, Barr MP, O'Byrne KJ and Gately K: Targeting nuclear factor-kappa B to overcome resistance to chemotherapy. Front Oncol 3: 120, 2013.

21. Bentires-Alj M, Barbu V, Fillet M, Chariot A, Relic B, Jacobs N, Gielen J, Merville MP and Bours V: NF-kappaB transcription factor induces drug resistance through MDR1 expression in cancer cells. Oncogene 22: 90-97, 2003.

22. Iseri OD, Kars MD, Arpaci F, Atalay C, Pak I and Gunduz U: Drug resistant MCF-7 cells exhibit epithelial-mesenchymal transition gene expression pattern. Biomed Pharmacother 65: 40-45, 2011. 
23. Saxena M, Stephens MA, Pathak $H$ and Rangarajan A Transcription factors that mediate epithelial-mesenchymal transition lead to multidrug resistance by upregulating $\mathrm{ABC}$ transporters. Cell Death Dis 2: e179, 2011.

24. Voulgari A and Pintzas A: Epithelial-mesenchymal transition in cancer metastasis: mechanisms, markers and strategies to overcome drug resistance in the clinic. Biochim Biophys Acta 1796: 75-90, 2009.

25. Yang HW, Menon LG, Black PM, Carroll RS and Johnson MD: SNAI2/Slug promotes growth and invasion in human gliomas. BMC Cancer 10: 301, 2010.

26. Wang SP, Wang WL, Chang YL, Wu CT, Chao YC, Kao SH, Yuan A, Lin CW, Yang SC, Chan WK, et al: p53 controls cancer cell invasion by inducing the MDM2-mediated degradation of Slug. Nat Cell Biol 11: 694-704, 2009.

27. Storci G, Sansone P, Trere D, Tavolari S, Taffurelli M,Ceccarelli C, Guarnieri T, Paterini P, Pariali M, Montanaro L, et al: The basallike breast carcinoma phenotype is regulated by SLUG gene expression. J Pathol 214: 25-37, 2008.

28. Lowe SW, Bodis S, McClatchey A, Remington L, Ruley HE, Fisher DE, Housman DE and Jacks T: p53 status and the efficacy of cancer therapy in vivo. Science 266: 807-810, 1994.

29. Dong P, Karaayvaz M, Jia N, Kaneuchi M, Hamada J, Watari H, Sudo S, Ju J and Sakuragi N: Mutant p53 gain-of-function induces epithelial-mesenchymal transition through modulation of the miR-130b-ZEB1 axis. Oncogene 32: 3286-3295, 2013.

30. Sheridan C, Kishimoto H, Fuchs RK, Mehrotra S, BhatNakshatri P, Turner $\mathrm{CH}$, Goulet R Jr, Badve $\mathrm{S}$ and Nakshatri $\mathrm{H}$ : CD $44^{+} / \mathrm{CD} 24^{-}$breast cancer cells exhibit enhanced invasive properties: an early step necessary for metastasis. Breast Cancer Res 8: R59, 2006.

31. van Oijen MG and Slootweg PJ: Gain-of-function mutations in the tumor suppressor gene p53. Clin Cancer Res 6: 2138-2145, 2000.

32. Tsou SH, Chen TM, Hsiao HT and Chen YH: A critical dose of doxorubicin is required to alter the gene expression profiles in MCF-7 cells acquiring multidrug resistance. PLoS One 10 e 01167472015

33. Ogretmen B and Safa AR: Expression of the mutated p53 tumor suppressor protein and its molecular and biochemical characterization in multidrug resistant MCF-7/Adr human breast cancer cells. Oncogene 14: 499-506, 1997.

34. Yu ST, Chen TM, Tseng SY and Chen YH: Tryptanthrin inhibits MDR1 and reverses doxorubicin resistance in breast cancer cells. Biochem Biophys Res Commun 358: 79-84, 2007.

35. Berglind H, Pawitan Y, Kato S, Ishioka C and Soussi T: Analysis of p53 mutation status in human cancer cell lines: a paradigm for cell line cross-contamination. Cancer Biol Ther 7: 699-708, 2008.

36. Nygren P, Larsson R, Gruber A, Peterson C and Bergh J: Doxorubicin selected multidrug-resistant small cell lung cancer cell lines characterised by elevated cytoplasmic $\mathrm{Ca}^{2+}$ and resistance modulation by verapamil in absence of P-glycoprotein overexpression. Br J Cancer 64: 1011-1018, 1991

37. Norberg T, Klaar S, Lindqvist L, Lindahl T, Ahlgren J and Bergh J: Enzymatic mutation detection method evaluated for detection of p53 mutations in cDNA from breast cancers. Clin Chem 47: 821-828, 2001.

38. Takahashi RU, Takeshita F, Honma K, Ono M, Kato K and Ochiya T: Ribophorin II regulates breast tumor initiation and metastasis through the functional suppression of GSK $3 \beta$. Sci Rep 3: 2474, 2013.

39. Li W, Liu C, Tang Y, Li H, Zhou F and Lv S: Overexpression of Snail accelerates adriamycin induction of multidrug resistance in breast cancer cells. Asian Pac J Cancer Prev 12: 2575-2580, 2011.

40. Ogretmen B and Safa AR: Negative regulation of MDR 1 promoter activity in MCF-7, but not in multidrug resistant MCF-7/Adr, cells by cross-coupled NF-kappa B/p65 and c-Fos transcription factors and their interaction with the CAAT region. Biochemistry 38: 2189-2199, 1999.

41. Tsai JH and Yang J: Epithelial-mesenchymal plasticity in carcinoma metastasis. Genes Dev 27: 2192-2206, 2013.
42. Nurwidya F, Takahashi F, Murakami A and Takahashi K: Epithelial mesenchymal transition in drug resistance and metastasis of lung cancer. Cancer Res Treat 44: 151-156, 2012.

43. Menon V and Povirk L: Involvement of p53 in the repair of DNA double strand breaks: multifaceted Roles of p53 in homologous recombination repair (HRR) and non-homologous end joining (NHEJ). Subcell Biochem 85: 321-336, 2014.

44. Wang Z and Sun Y: Targeting p53 for novel anticancer therapy. Transl Oncol 3: 1-12, 2010.

45. Oka M, Kounoura K, Narasaki F, Sakamoto A, Fukuda M, Matsuo I, Ikeda K, Tsurutani J, Ikuno N, Omagari K, et al: $\mathrm{P}$-glycoprotein is positively correlated with $\mathrm{p} 53$ protein accumulation in human colorectal cancers. Jpn J Cancer Res 88: 738-742, 1997.

46. Labialle S, Gayet L, Marthinet E, Rigal D and Baggetto LG: Transcriptional regulators of the human multidrug resistance 1 gene: recent views. Biochem Pharmacol 64: 943-948, 2002.

47. Wang LH, Okaichi K, Ihara M and Okumura Y: Sensitivity of anticancer drugs in Saos-2 cells transfected with mutant p53 varied with mutation point. Anticancer Res 18A: 321-325, 1998.

48. Chan KT and Lung ML: Mutant p53 expression enhances drug resistance in a hepatocellular carcinoma cell line. Cancer Chemother Pharmacol 53: 519-526, 2004.

49. Sosa AJ, Chavez P and Dyke KV: Inibitory effect of tetrandrine and paxlitaxel or doxorubicin on multi-drug-resistant (MDR) cancer cells associated with MDR-ATPase. Int J Pharmacother 4: $10,2014$.

50. Kim HG, Hien TT, Han EH, Hwang YP, Choi JH, Kang KW, Kwon KI, Kim BH, Kim SK, Song GY, et al: Metformin inhibits P-glycoprotein expression via the NF- $\kappa B$ pathway and CRE transcriptional activity through AMPK activation. Br J Pharmacol 162: 1096-1108, 2011.

51. Kajita M, McClinic KN and Wade PA: Aberrant expression of the transcription factors snail and slug alters the response to genotoxic stress. Mol Cell Biol 24: 7559-7566, 2004.

52. Fenouille N, Tichet M, Dufies M, Pottier A, Mogha A, Soo JK, Rocchi S, Mallavialle A, Galibert MD, Khammari A, et al: The epithelial-mesenchymal transition (EMT) regulatory factor SLUG (SNAI2) is a downstream target of SPARC and AKT in promoting melanoma cell invasion. PLoS One 7: e40378, 2012.

53. Roger L, Jullien L, Gire V and Roux P: Gain of oncogenic function of p53 mutants regulates E-cadherin expression uncoupled from cell invasion in colon cancer cells. J Cell Sci 123: 1295-1305, 2010.

54. Haslehurst AM, Koti M, Dharsee M, Nuin P, Evans K, Geraci J, Childs T, Chen J, Li J, Weberpals J, et al: EMT transcription factors snail and slug directly contribute to cisplatin resistance in ovarian cancer. BMC Cancer 12: 91, 2012.

55. Dhasarathy A, Phadke D, Mav D, Shah RR and Wade PA: The transcription factors Snail and Slug activate the transforming growth factor-beta signaling pathway in breast cancer. PLoS One 6: e26514, 2011

56. Catalano A, Rodilossi S, Rippo MR, Caprari P and Procopio A: Induction of stem cell factor/c-Kit/slug signal transduction in multidrug-resistant malignant mesothelioma cells. J Biol Chem 279: 46706-46714, 2004.

57. Bhat-Nakshatri P, Appaiah H, Ballas C, Pick-Franke P, Goulet R Jr, Badve S, Srour EF and Nakshatri H: SLUG/SNAI2 and tumor necrosis factor generate breast cells with $\mathrm{CD} 44^{+} / \mathrm{CD} 24$ phenotype. BMC Cancer 10: 411, 2010.

58. Sørlie T, Perou CM, Tibshirani R, Aas T, Geisler S, Johnsen H, Hastie T, Eisen MB, van de Rijn M, Jeffrey SS, et al: Gene expression patterns of breast carcinomas distinguish tumor subclasses with clinical implications. Proc Natl Acad Sci USA 98: 10869-10874, 2001.

59. Perou CM, Sørlie T, Eisen MB, van de Rijn M, Jeffrey SS, Rees CA, Pollack JR, Ross DT, Johnsen H, Akslen LA, et al: Molecular portraits of human breast tumours. Nature 406: $747-752,2000$

60. Gordon LA, Mulligan KT, Maxwell-Jones H, Adams M, Walker RA and Jones JL: Breast cell invasive potential relates to the myoepithelial phenotype. Int J Cancer 106: 8-16, 2003. 